\title{
RANCANG BANGUN KOMPONEN UTAMA PLTS OFF-GRID UNTUK MENUNJANG OPERASI INCINERATOR SIPESAT ${ }^{\circledR}$
}

\author{
Noor Hidayati $^{1 \otimes}$, Arifia Ekayuliana ${ }^{2}$ \\ ${ }^{1}$ Program Studi Terapan Teknik Manufaktur, Jurusan Teknik Mesin, Politeknik Negeri Jakarta, Jl. Prof. \\ G. A. Siwabessy, Kampus UI, Depok, 16425 \\ ${ }^{2}$ Program Studi Konversi Energi, Jurusan Teknik Mesin, Politeknik Negeri Jakarta, Jl. Prof. G. A. \\ Siwabessy, Kampus UI, Depok, 16425 \\ $\otimes_{e-m a i l}:{ }^{1}$ noor.hidayati@mesin.pnj.ac.id, ${ }^{2}$ arifia.ekayuliana@mesin.pnj.ac.id
}

\begin{abstract}
To increase reliability of SIPESAT ${ }^{\circledR}$ Incinerator, off-grid solar powerplant was installed. The aim of this paper is to designing the requirement of the main equipment for the solar powerplant. $270 \mathrm{w}, 3$ autonomies days were used as the main parameter. GHI gathered from NASA's data, VRLA battery type with MPPT inverter type was chosen to design the solar powerplant system. based on calculation results, the solar powerplant system need two solar panels 150watt each, and two VRLA battery 24V 200 Ah each,
\end{abstract}

Keywords : solar powerplant, SIPESAT ${ }^{\circledR}$, Incinerator, Off-grid

\begin{abstract}
Abstrak
Untuk meningkatkan kehandalan mesin incinerator milik SIPESAT ${ }^{\circledR}$ dilakukan pemasangan PLTS dengan system Off-Grid. Tujuan dari penelitian ini adalah untuk mendesign kebutuhan alat utama pada PLTS. Adapun Parameter yang ditentukan adalah kebutuhan daya incinerator sebesar 270 Watt dengan hari otonomi selama 3 hari. Untuk data GHI menggunakan data NASA. Tipe baterai terpilih adalah tipe VRLA, dan jenis MPPT inverter digunakan untuk system PLTS ini. setelah dilakukan perhitungan dibutuhkan 2 buah panel surya berdaya 150w dengan 2 baterai VRLA berkapasitas 24 V 200 Ah untuk memenuhi kebutuhan daya incinerator milik SIPESAT ${ }^{\circledR}$.
\end{abstract}

Kata kunci : PLTS, SIPESAT ${ }^{\circledR}$, Incinerator, Off-grid

\section{Pendahuluan}

\section{Latar Belakang}

SIPESAT ${ }^{\circledR}$ merupakan Perusahaan yang bergerak di bidang Pengelolahan sampah. Saat ini SIPESAT ${ }^{\circledR}$ memiliki modular incinerator untuk membakar sampah secara pyrolysis. Dalam modular tersebut terdapat fan dan blower. Hingga saat ini Fan dan blower pada modular incinerator milik SIPESAT $^{\circledR}$ masih menggunakan listrik dari PLN.

Untuk meningkatkan kehandalan mesin incenerator maka direncanakan untuk membuat listrik mandiri menggunakan tenaga surya. Listrik yang dihasilkan dari panel surya akan dimanfaatkan untuk menggerakan fan dan blower yang terdapat dalam mesin incinerator tersebut.

Tujuan dari penelitian ini adalah untuk merancang komponen utama system kelistrikan menggunakan system PLTS secara offgrid pada mesin incinerator milik SIPESAT $^{\circledR}$ agar dapat beroperasi mandiri tanpa memerlukan listrik dari PLN. Komponen utama yang akan ditentukan adalah jenis, jumlah, serta susunan panel surya, baterai, dan inverter PLTS.

\section{Dasar Teori}

Kebutuhan daya bangkitan diketahui menggunakan persamaan berikut:

$$
\begin{aligned}
& P_{\text {hari }}=t \times P_{\text {alat }} \\
& \mathrm{P}_{\text {hari }}=\text { kebutuhan daya per hari (watt) } \\
& \mathrm{P}_{\text {alat }}=\text { kebutuhan daya pada alat (watt) } \\
& \mathrm{t}=\text { Waktu (jam) }
\end{aligned}
$$

Luasan area pada PLTS dapat ditentukan berdasarkan intensitas radiasi pada lokasi yang ditentukan, serta suhu maksimum pada lokasi pemasangan. Adapun persamaan untuk menentukan luas minimum area 
pemasangan PLTS dapat dihitung memggunakan persamaan berikut [1]:

$$
\begin{aligned}
& \text { PV area }=\frac{P_{\text {hari }}}{\text { Gmin } \times T C F \times \eta P V \times \eta \text { out }} \\
& \mathrm{P}_{\text {hari }}=\text { kebutuhan daya per hari }(\mathrm{watt}) \\
& \mathrm{PV}_{\text {area }}=\text { Luas untuk Panel PV }\left(\mathrm{m}^{2}\right) \\
& \mathrm{G}_{\min }=\text { GHI minimum } \\
& \mathrm{TCF}=\text { Thermal correction Factor } \\
& \eta P V=\text { effisiensi solar panel } \\
& \text { Пout = effisiensi system }
\end{aligned}
$$

Global Horizontal Irradiance (GHI) atau radiasi matahari yang diukur pada permukaan horizontal, umunya diukur menggunakan Solarimeter, Pyranometer, atau radiometer. Bilamana, pyranometer tidak tersedia maka radiasi matahari dapat dihitung berdasarkan sinar matahari tercerah [2]. Terdapat dua sumber terpercaya dalam menyediakan data radiasi matahari global yaitu Website NASA [3] dan TUTIEMPO [4]. Pada data NASA data radiasi matahari diambil berdasarkan obeservasi menggunakan satelit, sedangkan data TUTIEMPO menggunakan data pengukuran darat. NASA menggunakan data rata-rata bulanan, sedangkan pada TUTIEMPO berbasiskan data perhari. Pada penelitian saat ini data menggunakan data NASA karena kelengkapan data dari tahun sebelumnya [2].

\section{Temperature Correction Factor (TCF)} Merupakan factor koreksi yang diperhitungkan untuk mengetahui performa panel surya. Perlu diketahui bahwa tiap kenaikan $1{ }^{\circ} \mathrm{C}$ dari suhu oprasi panel surya. Maka panel surya tersebut akan mengalami penuruan efisiensi sebesar 0,5\% [1]. Oleh karenaya, TCF perlu untuk dihitung, berdasarkan persamaan berikut [1]:

$$
\begin{aligned}
& P_{\Delta T}=0,5 \% \times P_{M p p} \times \Delta T \\
& P_{T_{o p}}=P_{M p p}-P_{\Delta T} \\
& T C F=\frac{P_{\Delta T}}{P_{M p p}}
\end{aligned}
$$

$P_{\Delta T}$

= Daya maksium dihasilkan pada saat temperature mengalami kenaikan $\Delta T$ (watt)

$P_{M p p}$

= Daya pada kondisi maksium power point (watt)
$\Delta T$

$=$ Perbedaan temperature pada kondisi standar panel dengan kondisi operasi $\left({ }^{\circ} \mathrm{C}\right)$

$P_{T_{o p}}$

= Daya maksium yang dihasilkan pada temperature operasi (watt)

Panel Surya, Secara garis besar terdapat berbagai macam teknologi panel surya. Baik panel surya yang terbuat dari kristalin maupun dari Thin film. Perusahaan independent NREL telah memplotkan perkembangan effisiensi panel surya sesuai pada Gambar 2 [5]

Berdasarkan Gambar 2, teknologi solar panel dibagi menjadi 4 teknologi besar yaitu sel surya berbasis multi junction, sel surya berbasis crystalline silica, sel surya berbasis teknologi thin film, dan sel surya berbasis teknologi PV terbaru (emerging PV). Hingga sekitaran tahun 2016 teknologi berbasis multi junction memiliki effisiensi tertinggi yaitu $46 \%$, untuk teknologi berbasis Kristal silika, konsentrator Kristal tunggal perusahaan Amonix memiliki effisiensi tertinggi sebesar 27,6\%. Sedangkan monocrystaline nonconcentrator tertinggi dimiliki oleh SunPower sebesar $25 \%$, dan polycrytaline silica oleh panasonik sebesar 25,6\%. Dari Teknologi thin film, CIGS konsentrator memiliki effisiensi sebesar 23,3\%. Dan dari teknologi terbaru emerging PV, CZTSSe memiliki effisiensi tertinggi di kelasnya dengan effisiensi $12,6 \%$.

Dari data pada Gambar 3, diketahui teknologi yang sudah dipakai secara luas dan komersial di dunia adalah teknologi kristal silika, baik berupa poly-cristaline/multicristaline dan mono-cristaline. Aplikasi panel surya teknologi kristalin sudah banyak digunakan di berbagai belahan bumi, sementara untuk teknologi thin-film masih dalam skala laboratorium maupun skala percontohan. Sampai sekarang, teknologi muti-junction masih menjadi teknologi sel surya yang terbaik dan banyak dipakai untuk program angkasa luar karena tahan terhadap radiasi dan panas, namun material dan teknologi fabrikasi untuk produksi massal masih terkendala. Panel surya yang digunakan harus mempunyai spesifikasi 
tertentu sesuai dengan sistem PLTS yang direncanakan. Parameter teknis panel mencakup hal-hal sebagai berikut:

- Jenis modul adalah Mono/Polycrystasiunlline Silicon.

- Output Modul Surya (Peak Power Output) per unit (ex: $150 \mathrm{Wp}$ ), karakteristik hasil tegangan tes Produsen harus terbaca pada modul (Manufacture, Serial Number, Peak Watt Rating, Peak Current, Peak Voltage, Open Circuit Voltage dan Short Circuit Current).

- Efisiensi modul surya minimum $16 \%$.

- Koneksi antar modul surya menggunakan koneksi plug-insocket.

- Keluaran array modul surya langsung ke String Inverter bergantung pada spesifikasi jumlah input String Inverter Inverter, berfungsi mengubah arus searah (DC) menjadi arus bolak-balik (AC). Listrik yang dibangkitkan oleh modul (panel) surya merupakan listrik arus searah (DC - direct current), sedangkan yang digunakan untuk kebutuhan manusia sehari-hari adalah listrik arus bolak balik (AC - alternating current). Agar sistem PLTS dapat bekerja paralel dengan jaringan sistem kelistrikan yang ada, diperlukan perangkat inverter.

Saat ini inverter telah dilengkapi dengan SCC/BCC yaitu solar charge controller/baterai charge controller. Fungsi alat ini untuk memlindungi baterai dari over charge dari panel surya atau over dischager [7]. Inverter yang digunakan harus mempunyai spesifikasi tertentu sesuai dengan sistem PLTS yang direncanakan. Parameter teknis inverter mencakup hal-hal sebagai berikut:

- Harus mampu memproduksi gelombang sinus murni

- Mempunyai effisiensi $\geq 95 \%$

- Total Harmonic Distortion (THD) $\leq 5 \%$

- Mempunyai sistem proteksi terhadap over current, over load, short circuits, over suhu, over/under voltage, reverse polarity

- Indicator (LCD display): power output, inverter voltage \& current, inverter frequency
Baterai merupakan alat penyimpan energy listrik. Baterai dibutuhkan terutama pada rangkaian off-grid. Dalam perancangan kebutuhan baterai terdapat beberapa factor yang harus diperhatikan seperti Dod (depth of discharge), jumlah siklus, effisiensi baterai, discharge rate dan suhu. depth of discharge merupakan presentasi keluaran energy dari baterai, semakin tinggi nilai Dod semakin pendek umur baterai [7]. Umur baterai juga dilihat dari jumlah siklus. Satu siklus baterai dihitung dari satu kali keluaran dan satu kali pengisian. Semakin banyak jumlah siklus perhari maka umur baterai akan semakin pendek. Sebagai contoh bila dalam satu hari dilakukan satu siklus baterai sedangkan baterai tersebut memiliki 2000 cycle, maka umur baterai adlah 2000 dibagi 365 hari yaitu sekitar 5 tahun, namun apabila dalam sehari dilakukan 3kali siklus maka umur baterai menjadi 2000 dibagi dengan 3/365 hari yaitu 1,8 tahun. Karena baterai juga memiliki internal resisten maka terdapat rugi-rugi didalam baterai. Umumnya dalam 1 siklus effisiensi baterai sekitar $75 \%$.. effisiensi round trip merupakan efisiensi dalam 1 siklus. Untuk suhu, baterai dapat berkerja maksimal pada suhu tinggi, namun hal tersebut dapat mempersingkat umur baterai, suhu ideal baterai adalah 20-25oC [7]. Discharge Rate pada baterai disimbolkan dengan Cxx, Cxx mengartikan arus yang dapat dikeluarkan dalam xx jam. Sebagai contoh pada baterai 1000 ah dengan C20 mengartikan bahwa baterai tersebut dapat mengeluarkan arus $1000 \mathrm{Ah}$ dalam $20 \mathrm{jam}$. Atau perjamnya $1000 \mathrm{Ah} / 20 \mathrm{jam}=50 \mathrm{~A}$. apabila dalam pemakiannya perjamnya baterai harus berkerja diatas kapasitasnya misal 100 A .hal tersebut akan mempersingkat waktu pakai baterai, dapat dilihat secara perhitungan berikut $1000 \mathrm{Ah} / 100 \mathrm{~A}=10$ hours. Jadi dapat dilihat bila arus yang dikeluarkan perjamnya sebesar 100 A maka waktu pakai baterai akan berkurang setengahnya yaitu hanya 10 jam. Untuk baterai pada system off-grid harus mempertimbangkan factor sebagai berikut [7] : 
- Memiliki system ventilasi/ katup pengatur VRLA (Valve Regulated Lead Acid)

- Baterai berjenis deep cycle

- Kapasitas baterai minimal 1800 Ah pada C20 discharge

- Jumlah Cycle baterai minimal adalah 2000 Cycle pada Dod 80\%,C20

- Kapasitas baterai yang didesain dapat bertahan untuk 3 hari otonomi

- Dod maksimal 80\%

- Dod harian pada off-grid sebesar 50\%

- Mampu berkerja pada suhu $450 \mathrm{oC}$

\section{Metode Penelitian}

Pada bagian ini akan dijelaskan mengenai tahapan penelitian yang digambarkan pada Gambar 3. Tahap pertama dilakukan study litertature terkait rancang bangun PLTS khususnya pada off-grid. Tahap selanjutnya adalah pengumpulan data. Data kebutuhan listrik dan lokasi pemasangan didapatkan memalui survey alat langsung dan interview. Setelah mengumpulkan data, tahap perancangan selanjutnya adalah menentukan parameter. Tahapa ini diperlukan sebagai batasan dalam mendesign. Adapun parameter yang di tentukan sepeerti jenis baterai, jenis panel surya,serta jenis inverter yang digunakan.

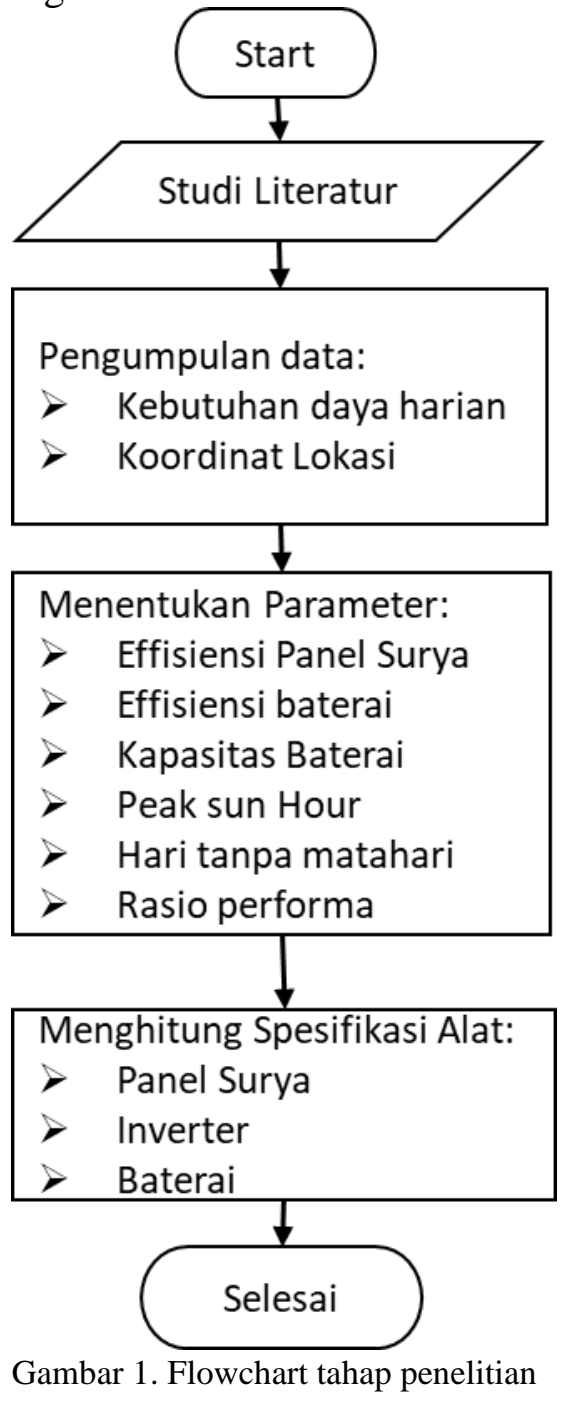

\section{Hasil dan Pembahasan}

Berdasarkan hasil interview dan survey lokasi, daya yang dibutuhkan untuk menghidupkan blower dan fan masingmasing sebesar 180watt dan 90watt. Estimasi Waktu pemakaian per hari saat ini 2 jam. Ditambah dengan 1 jam untuk factor keamanan,sehingga total waktu adalah 3 jam, dan untuk daya yang dibutuhkan sebesar 270 watt, didapatkan dari penjumlahan daya 180 dan 90 watt yang berasal dari blower dan fan.Sehingga kebutuhan daya selama satu hari adalah pengkalian 3 jam dengan $270 \mathrm{w}$

$$
\begin{aligned}
& P_{\text {hari }}=t \times P_{\text {alat }} \\
& P_{\text {hari }}=810 \mathrm{Wh} .
\end{aligned}
$$


Intensitas Matahari dan Suhu Maksimum. Berdasarkan koordinat lokasi. Data GHI atau intensitas radiasi matahari dan suhu maksimum matahari dapat diketahui dengan memasukan data latitude dan longtidtude lokasi ke dalam web NASA [3]. Data intensitas radiasi dan suhu maksimum yang diambil dari data NASA dari tahun 19902019 dapat dilihat pada Tabel 1.

Data Insolasi Matahari $\left(\mathrm{kWh} / \mathrm{m}^{2} /\right.$ Hari $)$ diambil pada kondisi all-sky yaitu data radiasi matahari yang jatuh secara horizontal pada permukaan bumi, diambil pada kondisi berawan selama duapuluh sembilan tahun 1990-2019.

Dari data Tabel 1, diambil nilai tahunan minimum sebesar $4.48 \mathrm{kWh} / \mathrm{m}^{2} /$ Hari. Tujuan dari pengambilan nilai minimum ini adalah agar PLTS dapat tetap berkerja secara optimal pada saat radiasi berada dititik minimumnya. sedangkan untuk suhu, diambil data tertinggi untuk mendapatkan factor koreksi suhu [1]. Dari data NASA yang dapat dilihat pada Tabel 2, didapatkan suhu tertinggi selama duapuluh Sembilan tahun adalah $32,92^{\circ} \mathrm{C}$.

\section{Penentuan Parameter}

Dalam mendesain PLTS terutama secara offgrid ada beberapa parameter yang harus ditetapkan seperti Durasi Pengoperasian, Hari Tanpa Matahari, Dod (deep of discharge) dan Peak Sun Hour. Durasi Pengoperasian merupakan lamanya waktu fan dan blower digunakan selama sehari. Berdasarkan hasil interview diketahui bahwa alat berkerja selama 2 jam ditiap harinya, namun karena mempertimbangkan faktor kenyamanan dan keamanan maka ditentukan waktu pengoperasian alat diestimasi selama 3 jam tiap harinya.

Untuk mendesign kebutuhan baterai maka terlebih dahulu ditentukan kemungkinan hari tanpa matahari/otonimi. Dalam rancangan ini ditentukan 3 hari tanpa matahari. Hal ini bertujuann agar alat fan dan blower dapat tetap menyala meskipun tidak terdapat matahari atau dalam tiga hari mendung maupun hujan.

Selain hari tanpa matahari,salah satu factor yang ditentukan adalah Dod (deep of discharge). Dod merupakan parameter yang menunjukan besarnya keluaran energy dari baterai yang ditunjukan dalam bentuk presentase dari nominal kapasitas baterai. Semakin besar angka Dod maka semakin besar energy yang dikeluarga dari baterai tersebut. Hal ini akan berpengaruh pada keawetan umur baterai. Semakin tinggi Dod maka umur baterai semakin pendek. Oleh karena itu umunya dalam PLTS, Dod didesain sebesar 25\% - 30\%. Apabila Dod ditentukan sebesar 25\%-35\% umur baterai dapat diperkirakan sampai 5 tahun. Baterai dengan DoD 50\% akan memiliki umur lebih panjang dua kali. Jika DoD 10\%, maka umurnya akan bertambah 5 kali dari DoD $50 \%$. Konsekuensinya adalah tingginya biaya baterai [7].Untuk mencapai keseimbangan antra keawetan dan keekonomisan harga maka ditentukan Dod dalam system PLTS kali ini sebesar $50 \%$.

Parameter penting lainnya yaitu Peak Sun Hour, merupakan Waktu optimal pengisian daya oleh matahari kepada system PLTS. diIndonesia waktu optimal pengisian matahri dalama sehari hanya selama 4 jam [7].tipe batrai ditentukan dengan baterai yang memiliki tegangan 24V 200 AH jenis VRLA, sedangkan untuk jumlah dan susunan baterai akan diketahui melalui perhitungan disubab selanjutnya. Dalam menentukan kebutuhan baterai sangat erat kaitanya dengan jenis inverter yang dipilih. Dalam hal ini jenis inverter terpilih adalah inverter dengan tipe MPPT effisiensi inverter 95\% dengan tegangan output inverter 220 VAC

Selain baterai parameter lain yang ditentukan adalah jenis, effisiensi, dan spesifikasi panel yang akan digunakan. Penentuan panel dilakukan diawal guna mempermudah penentuan jumlah keperluan panel dan komponen lainnya. Dalam rancangan kali ini didesain menggunakan panel surya tipe polycrystalin dengan daya Pmpp 150 Watt, 
dan effisiensi 16\%, memiliki Vmp 17,6 V dengan Imp 8,55 A.

\section{Menghitung Kebutuhan Alat Utama dan Susunannya}

Setelah mengetahui kebutuhan daya, energy yang di peroleh dari matahari, dan menentukan parameter, langkah berikutnya adalah menentukan kebutuhan dan susunan alat berdasarkan parameter yang telah ditentukan, dan sumber energy yang ada.

\section{Perhitungan Luas Area .}

Panel surya akan mengalami penurunan performa apabila dioperasikan pada suhu tinggi [8].oleh karena itu perlu dilakukan koreksi daya keluaran berdasarkan suhu. Solar panel pada kondisi standar yaitu pada $25^{\circ} \mathrm{C}$ akan mengalami penurunan performa apabila dipasangkan pada kondisi suhu maksimum $32,92^{\circ} \mathrm{C}$. dari data tersebut diketahui selisih suhu standar dengan suhu maksimum sebesar $7,92^{\circ} \mathrm{C}$. dengan daya maksimum power point ( $\mathrm{P}_{\mathrm{MPP}}$ ) Panel diketahui sebesar 150 watt,dan penurunan effisiensi panel sebesar $0,5 \%$. maka daya yang hilang pada suhu maksimum dapat dihitung dengan persamaan berikut [1].

$$
\begin{aligned}
P_{\Delta T} & =0,5 \% \times P_{M p p} \times \Delta T \\
& =5,94 \mathrm{~W}
\end{aligned}
$$

Dari perhitungan diatas diketahui, bahwa pada suhu maksimum panel akan kehilangan daya sebesar 5,94 watt, sehingga daya yang keluar pada suhu operasi yaitu selisih dari daya maksimum power point ( $\mathrm{P}_{\mathrm{MPP}}$ ) Panel dengan daya daya yang hilang pada suhu maksimum, yaitu 144,06 Watt, sesuai perhitungan dibawah ini.

$$
\begin{aligned}
P_{T_{o p}} & =P_{M p p}-P_{\Delta T} \\
& =144,06 \mathrm{~W}
\end{aligned}
$$

Untuk mengetahui berapa persen factor koreksi daya keluaran panel yang disebabkan oleh suhu operasi dapat dilakukan perhitungan sebagai berikut.

$$
\begin{aligned}
& \mathrm{TCF}=\frac{P_{T_{o p}}}{P_{M p p}} \times 100 \% \\
& \mathrm{TCF}=96 \%
\end{aligned}
$$

Dari persamaan di atas diketahui, nilai TCF didapatkan dengan membagi daya keluaran pda temperature operasi yaitu 144,06 watt dengan daya maksimum panel yaitu 150, dikalikan $100 \%$ maka didapatkan nilai TCF adalah $96 \%$.

Dengan Nilai TCF sebesar 96\%, dengan mengasumsikan effisiensi system PLTS sebesar 95\%, serta kebutuhan daya perhari sebesar 0,81 kWh, dan Global horizontal irradiance minimal tahunan yang didapatkan dari data nasa sebesar $4,48 \frac{\frac{k W h}{m 2}}{d a y}$ dan effisiensi panel $16 \%$, maka kebutuhan luas aktif dari PV dapat dihitung menggunakan persamaan berikut [1] :

PV area

$$
=\frac{P_{\text {hari }}}{G \min \times T C F \times \eta P V \times \eta \text { out }}
$$

PV Area $=1,24 \mathrm{~m}^{2}$

Dari perhitungan diatas didapatkan bahwa luasan aktif area minimal sebesar $1,24 \mathrm{~m}^{2}$

\section{Perhitungan Kebutuhan Panel}

Nilai TCF digunakan juga untuk menentukan kebutuhan solar panel. Diketahui kebuthan daya harian adalah sebesar $810 \mathrm{Wh} / \mathrm{hari}$, dan pada penentuan parameter telah ditentukan panel dengan daya bangkitan maksimum $\left(\mathrm{P}_{\mathrm{mpp}}\right) 150 \mathrm{Wp}$,dengan PSH selama 4 jam maka jumlah solar panel yang dibutuhkan dapat dicari mengguanakan perhitungan berikut :

$P_{\text {max } \text { ideal }}=P_{\text {mpp Panel }} \times P S H$

$P_{\text {max ideal }}=600 \mathrm{wh}$

600 Wh merupakan daya keluaran pada kondisi ideal yang diukur pada suhu $25^{\circ} \mathrm{C}$. oleh karenanya nilai tersebut harus dikoreksi dengan factor suhu (TCF) . sehingga daya bangkitan dengan memperhitungkan factor suhu operasi dapat dihitung sebagai berikut :

$$
\begin{aligned}
& P_{W p_{\text {tem }}}=P_{\text {maxideal }} \times T C F \\
& P_{W p_{\text {tem }}}=600 \mathrm{wh} \times 96 \% \\
& P_{W p_{\text {tem }}}=576 \mathrm{wh}
\end{aligned}
$$

Untuk mengetahui berapa banyak panel yang diperlukan untuk membangkitkan $810 \mathrm{Wp}$ per hari dapat dilakukan dengan membagi Kebuthan daya harian yaitu $810 \mathrm{Wh}$ dengan $P_{W p_{\text {tem }}} 576 \mathrm{Wh}$ 
Jumlah Panel $=\frac{\text { Kebuthan daya harian }}{P_{W p_{\text {tem }}}}$ Jumlah Panel $=1,4$ Buah

Dari hasil perhitungan didapatkan nilai 1,4 buah panel Dibulatkan menjadi 2 panel. Jadi untuk memenuhi kebutuhan daya 810 $\mathrm{kWh} /$ hari dibutuhkan dua buah solar panel dimana, tiap satu panel memiliki daya sebesar 150watt. Sehingga total daya bangkitan menggunakan 2 panel menjadi 300 Wp.

\section{Penyusunan Seri parallel Panel surya}

Untuk mengetahui susunan seri atau parallel suatu solar panel harus terlebih dahulu dipahami konsep pada saat panel surya disusun secara seri yaitu kutub positif dipertemukan dengan kutup negative panel lainnya, maka hal tersebut akan menaikan nilai tegangan dan nilai arus tetap. Sedangkan, saat panel disusun parallel dimana kutub positif bertemu dengan kutub positif panel lainnya, akan menaikan nilai arus dengan nilai tegangan tetap [7].

Selain itu, untuk mendapatkan jenis susunan panel perlu diketahui tegangan system baterai yang dipilih, dalam hal ini tegangan yang dipilih adalah $24 \mathrm{~V}$ dan $\mathrm{V}$ panel 17,6 V. maka jumlah panel disusun seri sebanyak:

$$
\text { jumlah panel seri }=\frac{V_{\text {baterai }}}{V_{\text {panel }}}
$$

jumlah panel seri $=1,36$

Dibulatkan menjadi 2 buah disusun secara seri. Dan jumlah panel disusun parallel dapat dihitung sebagai berikut :

jumlah panel paralel

$=\frac{\text { jumlah panel disusun seri }}{\text { jumlah panel yang dibutuhkan }}$

Jumlah panel disusun seri sebanyak 2 buah, dan jumlah panel yang dibutuhkan sebanyak 2. Sehingga didapatkan jumlah panel disusun parallel sebanyak 1 buah Dengan tegangan panel perbuah sebesar 17,6 $\mathrm{V}$ dan jumlah seri 2 panel maka dapat dicek tegangan string sebesar $35,2 \mathrm{~V}$

$$
\begin{aligned}
& V_{\text {panel }_{\text {seri }}}=V_{\text {panel }} \times \text { jumlah panel seri } \\
& V_{\text {panel }_{\text {seri }}}=35,2 \mathrm{~V}
\end{aligned}
$$

Diketahui dari perhitungan untuk tegangan string panel sebesar $\left(V_{\text {string }}\right) 35,2 \mathrm{~V}$ dan arus tetap 8,55 A maka daya yang dibangkitkan dapat dihitung dengan mengkalikan tegangan dan arus string sebagai berikut :

$P=I_{\text {string }} \times V_{\text {string }}$

$P=300,96 \mathrm{~W}$

Nilai bangkitan sebesar 300,96 watt mendekati 300 watt. Sehingga sesuai dengan daya bangkitan yang diperlukan.

\section{Menentukan Kapasitas Baterai}

Besar kapasitas baterai yang dibutuhkan dapa dihitung melalui persamaan berikut [1]:

$$
\begin{aligned}
& \mathrm{C}_{\text {baterai }}=\frac{\text { Hari } \text { tanpa } \text { matahari } \times \text { Kebutuhan daya }}{\text { tegangan } \text { sistem } \times D O D \times \mathrm{n}} \\
& \mathrm{C}_{\text {baterai }}=145,33 \mathrm{Ah}
\end{aligned}
$$

Dengan hari tanpa matahari selama 3 hari, dengan daya yang dibutuhkan perhari $810 \mathrm{w}$, dan tegangan system sebesar $35,2 \mathrm{~V}$ dan DOD baterai $50 \%$ serta effisiensi baterai $95 \%$ maka didapatkan capasitas baterai yang dibutuhkan sebesar 145,33 Ah

Karena telah ditentukan baterai yang dipilih memiliki spesifikasi 24V 200 Ah maka susunan baterai dapat diketahui sebagai berikut

$\mathrm{N}_{\text {baterai seri }}=\frac{V_{\text {string }}}{V_{\text {Baterai }}}$

Dengan nilai tegangan string sebesar $35,2 \mathrm{~V}$ dan tegangan baterai terpilih sebesar $24 \mathrm{~V}$ maka jumlah baterai yang disusun seri sebesar 1,47 dibulatkan menjadi 2 buah.

Untuk baterai yang disusun parallel dapat dicari dengan membagi kapasitas baterai 145,33 Ah dengan kapasitas baterai terpilih yaitu $200 \mathrm{Ah}$

$$
\begin{aligned}
& \mathrm{N}_{\text {baterai Paralel }}=\frac{C_{\text {baterai }}}{C_{\text {Ah terpilih }}} \\
& \mathrm{N}_{\text {baterai Paralel }}=0,7
\end{aligned}
$$


Sehingga baterai disusun seri dibulatkan sebanyak 1 buah. Perlu diketahui bahwa saat baterai disusun secara parallel maka akan meningkatkan tegangan dan arus tetap, namun saat baterai disusun seri akan menaikan arus dan tegangan tetap, Kebalikan dari konsep seri parallel pada panel surya. Dan baterai disusun seri adalah 1. Sehingga output baterai 48V 200 Ah.

\section{Menentukan Kapasitas Inverter}

Inverter yang sudah dilengkapi SCC secara internal maka SCC external dapat ditiadakan. Jenis inverter yang dipilih saat ini adalah MPPT karena dapat mengambil energi maksimal dari solar panel.kapasitas inverter yang dibutuhkan dapat dilihat berdasarkan persamaan berikut [7]

$$
\begin{aligned}
C_{\text {inverter }}= & \text { factor safety } \\
& \times \text { beban puncak }
\end{aligned}
$$

Factor safety ditentukan sebesar $125 \%$ dengan beban puncak sebesar $270 \mathrm{~W}$ didapatkan $C_{\text {inverter }}$ sebesar $351 \mathrm{w}$

Dimana tegangan system baterai atau Vdc sebesar $48 \mathrm{~V}$ yang juga diseting menjadi tegangan pada inverter

$$
\begin{gathered}
I_{\text {inverter }}=\frac{C_{\text {inverter }}}{V_{\text {inverter }}} \\
I_{\text {inverter }}=7,03 \mathrm{~A}
\end{gathered}
$$

\section{KESIMPULAN}

Untuk memenuhi kebutuhan fan dan blower dibutuhkan dua buah solar panel polikristalin berdaya $150 \mathrm{Wp}$. yang disusun secara seri.Yang dilengkapi dengan Inverter bertipe MPPT yang telah dilengkapi dengan SCC dengan kapasitas minimum 351 watt dan harus mampu dilewati arus sebesar 7,03A. system PLTS bersifat off-grid atau stand alone yang harus dilengkapi dengan baterai bertipe VRLA berjumlah 2 buah yang disusun secara seri sehingga output baterai sebesar 48V 200AH.

\section{Ucapan Terima kasih}

Penulis mengucapkan terima kasih kepada Pak Singgih Lelono sebagai pendiri dari SIPESAT $^{\circledR}$ atas kerja samanya serta kepada Bapak Fachruddin atas kesempatan yang diberikan dan bimbingannya.

\section{Daftar Pustaka}

[1] V. R. Kossi, "Perencanaan Plts Terpusat (Off-Grid) Didusun Tikalong Kabupaten Mempawah," Jurnal Teknik Elektro Universitas Tanjungpura, 2018.

[2] H. L. Zhang, J. Baeyens, J. Degreve dan G.Caceres, "Concentrated solar power plants: Review and design methodology," Renewable and Sustainable Energy Reviews, vol. 22, pp. 466-481, 2013.

[3] Stackhouse, Jr., Ph.D, Paul ; Barnett, A Jason ; Macpherson, Bradley; Zhang, Taiping ; Mikovitz, Colleen ;" "NASA POWER," NASA langley Research Center, 25 February 2020. [Online]. Available:

https://power.larc.nasa.gov/data-accessviewer/. [Diakses 2 February 2021].

[4] https://en.tutiempo.net/,[Online].

[5] N.Kopidakis, https://www.energy.gov/eere/solar/down loads/research-cell-efficiency-records [Online]. [Diakses 9 february 2021].

[6] "https://www.energy-transitioninstitute.com/insights/solarphotovoltaic," A.T Kearney Energy Transition Institute. [Online]. [Diakses 9 february 2021].

[7] R. Sianipar, "Dasar Perencanaan Pembangkit Listrik," Jetri : Jurnal Ilmiah Teknik Elektro, vol. 11, no. 2, pp. 61-78, 2014

[8] S. Bailey dan R. Raffaelle, "Operation of Solar Cells in a Space Environment," dalam Practical handbook Of Photovoltaics Fundamental And Applications, Waltham-MA-USA, Elsevier Ltd, 2012, p. 870 


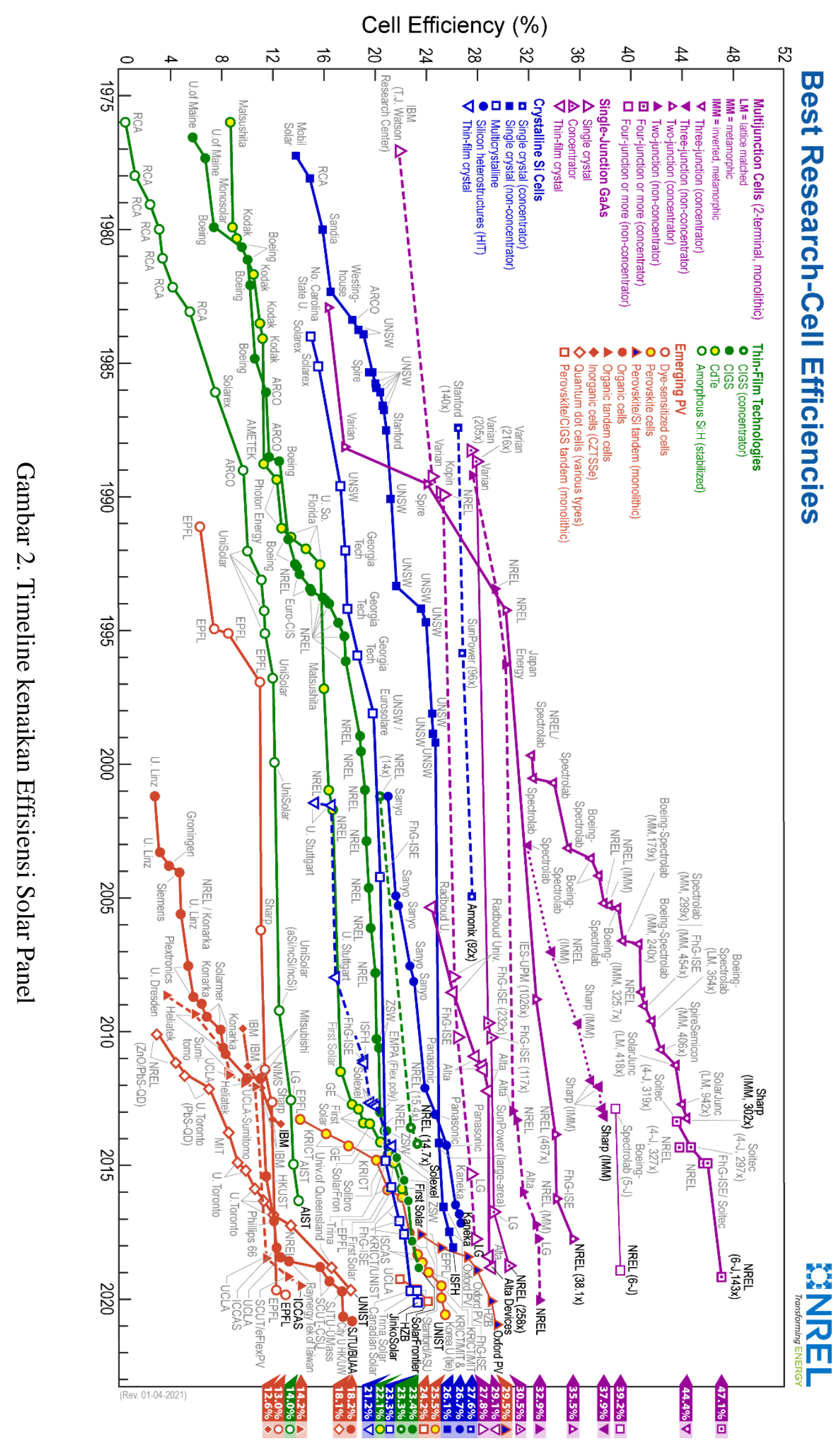


Noor Hidayatim Arifia Ekayuliana, dkk., Rancang Bangun...

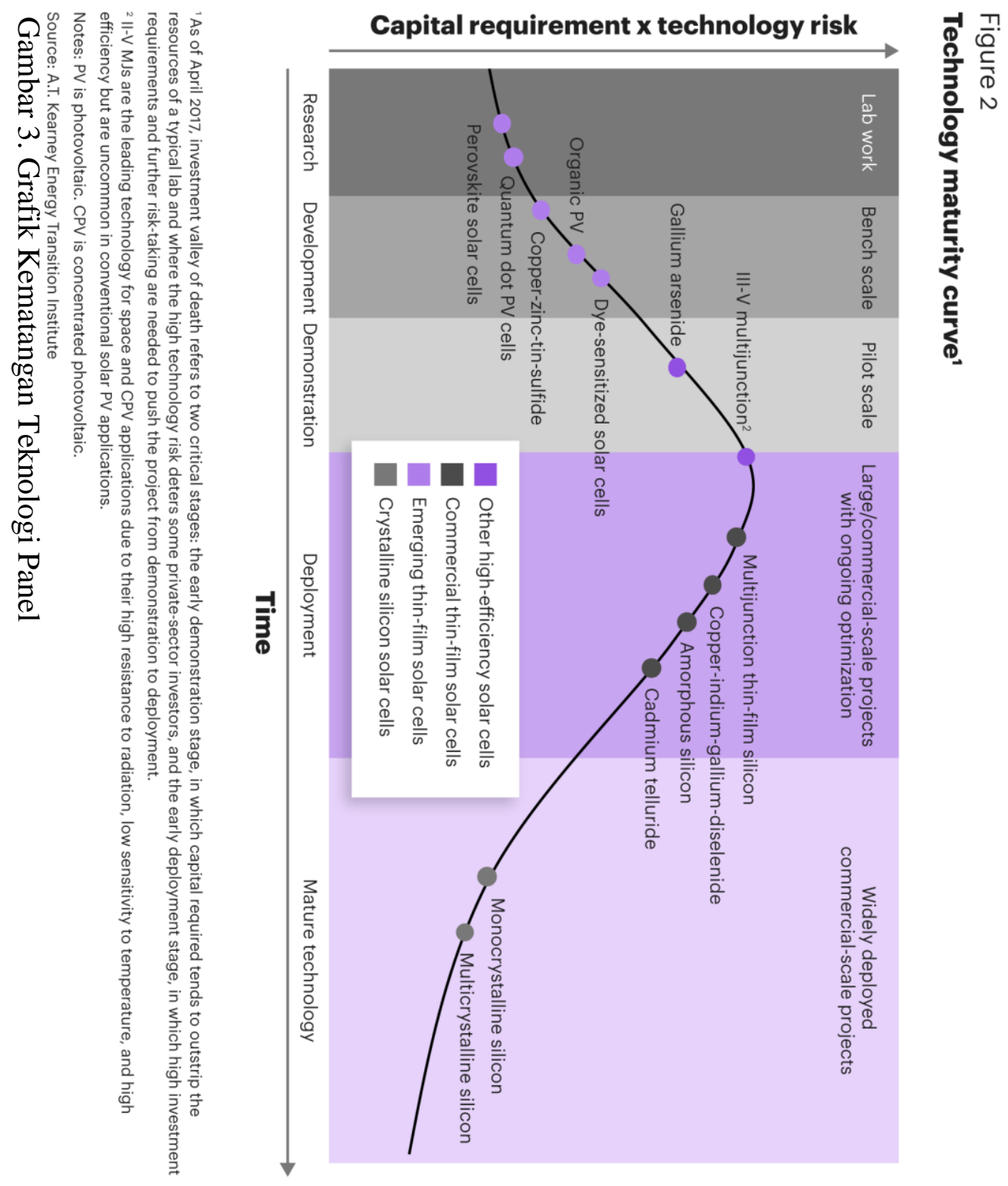


Tabel 1. GHI Cawang-Jakarta 1990-2019 pada all sky condition [3]

\begin{tabular}{|c|c|c|c|c|c|c|c|c|c|c|c|c|c|}
\hline YEAR & JAN & FEB & MAR & APR & MAY & JUN & JUL & AUG & SEP & OCT & NOV & DEC & ANN \\
\hline 1990 & 3.77 & 4.73 & \begin{tabular}{|l|}
4.49 \\
\end{tabular} & 5.11 & 4.71 & 4.65 & 4.76 & $\begin{array}{l}4.8 \\
\end{array}$ & 5.53 & 5.69 & 5.64 & 4.42 & 4.85 \\
\hline 1991 & 4.24 & 3.65 & 5 & 4.71 & 4.93 & 4.97 & 5.06 & 5.67 & 5.92 & 5.77 & 4.9 & 4.54 & 4.95 \\
\hline 1992 & 4.85 & 4.84 & 5.12 & 5 & 4.78 & 4.87 & 4.83 & \begin{tabular}{l|l}
4.62 \\
\end{tabular} & 4.88 & 4.19 & 4.54 & 4.43 & 4.74 \\
\hline 1993 & 4.19 & 4.53 & 5.05 & 4.69 & 4.71 & 4.57 & 5.01 & 5 & 5.63 & 5.84 & 4.55 & 4.01 & 4.82 \\
\hline 1994 & 3.66 & 4.02 & 4.58 & 4.43 & 4.86 & 4.79 & 5.27 & 5.53 & 5.79 & 5.75 & 5.1 & 4.77 & 4.89 \\
\hline 1995 & 3.91 & 4.44 & \begin{tabular}{l|}
4.71 \\
\end{tabular} & 5.05 & 4.76 & 4.26 & 4.59 & 5.42 & 5.42 & 4.87 & 3.88 & 3.78 & 4.59 \\
\hline 1996 & 4.04 & 4.31 & 4.74 & 4.71 & 4.72 & 4.49 & 4.72 & 5.16 & 5.28 & \begin{tabular}{|l|}
4.48 \\
\end{tabular} & 4.67 & 3.8 & 4.59 \\
\hline 1997 & 4.32 & 4.23 & 5.54 & 4.58 & 4.7 & 5.1 & 5.15 & 5.58 & 6.13 & 5.98 & 5.35 & 4.99 & 5.14 \\
\hline 1998 & 4.84 & 4.64 & 5.04 & 4.51 & 4.55 & 3.96 & 4.16 & 4.83 & 5.41 & 4.29 & 4.02 & 4.19 & 4.54 \\
\hline 1999 & 3.82 & 3.99 & 4.66 & 4.67 & 4.37 & 4.7 & 4.93 & 5.38 & 5.78 & 5.11 & 4.49 & 4 & 4.66 \\
\hline 2000 & 4.04 & 4.34 & 4.25 & 4.77 & 4.5 & 4.25 & 4.71 & 5.14 & 5.81 & \begin{tabular}{|l|}
4.99 \\
\end{tabular} & 4.05 & 5.05 & 4.66 \\
\hline 2001 & 4.42 & 3.78 & \begin{tabular}{l|l}
4.3 \\
\end{tabular} & 4.9 & 4.58 & 4.56 & 4.73 & \begin{tabular}{l|l}
5.3 \\
\end{tabular} & 5.34 & 4.26 & 3.97 & 5.08 & 4.61 \\
\hline 2002 & 4.44 & 3.86 & $\begin{array}{ll}4.89 \\
\end{array}$ & 4.61 & 4.48 & 4.57 & 4.55 & 5.3 & 5.98 & 6.01 & 4.85 & 4.3 & 4.83 \\
\hline 2003 & 5.03 & 3.72 & 4.61 & 4.72 & 4.78 & 4.67 & 5.24 & 5.35 & 5.31 & 4.71 & 4.81 & 3.95 & 4.75 \\
\hline 2004 & 4.53 & 3.67 & 4.9 & 5.11 & 4.35 & 4.54 & 4.68 & 5.57 & 5.46 & 5.74 & 4.52 & 4.16 & 4.77 \\
\hline 2005 & 4.61 & 4.27 & 4.33 & 4.61 & 4.73 & 4.4 & 4.85 & 5.26 & 5.09 & 4.79 & 4.88 & 3.92 & 4.65 \\
\hline 2006 & 4.1 & 4.52 & 4.31 & 4.37 & 4.69 & 4.53 & 4.91 & 5.79 & 6.35 & 6.2 & 5.66 & 4.42 & 4.99 \\
\hline 2007 & 5 & 4.21 & 4.16 & 4.37 & 4.48 & 4.44 & 4.76 & 5.67 & 6.02 & 5.5 & 5.22 & 3.79 & 4.81 \\
\hline 2008 & 5.13 & 3.87 & 4.69 & 4.67 & 4.98 & 4.74 & 5.36 & 4.95 & 5.67 & 5.21 & 4.23 & 4.43 & 4.83 \\
\hline 2009 & 4.32 & 4.24 & 5.37 & 4.85 & 4.46 & 4.65 & 5.19 & 5.62 & 5.95 & 5.52 & 4.75 & 4.93 & 4.99 \\
\hline 2010 & 4.38 & 5.05 & \begin{tabular}{l|l|}
4.87 \\
\end{tabular} & 5.39 & 4.09 & 3.89 & 4.21 & \begin{tabular}{l|l}
4.79 \\
\end{tabular} & 4.6 & 4.71 & 4.55 & 4.16 & 4.55 \\
\hline 2011 & 4.32 & 4.72 & 4.52 & 4.69 & 4.4 & 4.74 & 4.92 & 5.69 & 5.92 & 5.27 & 4.77 & 4.78 & 4.89 \\
\hline 2012 & 4.2 & 5.3 & 5.06 & 4.87 & 4.54 & 4.81 & 5.1 & 5.66 & 6.01 & 5.48 & 4.63 & 4.71 & 5.03 \\
\hline 2013 & 3.67 & 5 & \begin{tabular}{|l|}
5.27 \\
\end{tabular} & 4.48 & 4.08 & 4.18 & 3.88 & 5.5 & 5.4 & 5.43 & 4.93 & 4.46 & 4.69 \\
\hline 2014 & 3.97 & 4.45 & 4.96 & 4.98 & 4.48 & 4.2 & 4.39 & 5.39 & 6.02 & 5.63 & 4.89 & 4.38 & 4.81 \\
\hline 2015 & 4.33 & 4.69 & 4.72 & 4.5 & 4.83 & 4.85 & 5.05 & 5.59 & 5.89 & 6.03 & 5.07 & 4.63 & 5.02 \\
\hline 2016 & 4.94 & 4.13 & 4.8 & 4.82 & 4.04 & 4.24 & 4.59 & 4.88 & 4.75 & 4.01 & 4.25 & 4.28 & 4.48 \\
\hline 2017 & 4.51 & 3.76 & 4.82 & 4.79 & 4.4 & 4.13 & 4.62 & 5.25 & 5.33 & 5.05 & 4.6 & 4.22 & 4.61 \\
\hline 2018 & 4.09 & 4.8 & 5.15 & 4.82 & 4.64 & 4.51 & 5.21 & 5.36 & 5.42 & 5.43 & 4.55 & 4.62 & 4.87 \\
\hline 2019 & 4.55 & 5.23 & 4.59 & 4.89 & 4.75 & 4.95 & 5.16 & 5.51 & 5.92 & 6.07 & 5.81 & 4.7 & 5.14 \\
\hline Rata-rata & 4.34 & 4.37 & 4.78 & 4.76 & 4.58 & 4.54 & 4.82 & 5.32 & 5.60 & 5.27 & 4.74 & 4.40 & 4.79 \\
\hline Maksimum & 5.13 & 5.30 & 5.54 & 5.39 & 4.98 & 5.10 & 5.36 & 5.79 & 6.35 & 6.20 & 5.81 & 5.08 & 5.14 \\
\hline Minimum & 3.66 & 3.65 & 4.16 & 4.37 & 4.04 & 3.89 & 3.88 & 4.62 & 4.60 & 4.01 & 3.88 & 3.78 & 4.48 \\
\hline
\end{tabular}

Tabel 2. Suhu Maksimum di Cawang-Jakarta dari tahun 1990-2019 [3].

\begin{tabular}{|c|c|c|c|c|c|c|c|c|c|c|c|c|c|}
\hline YEAR & JAN & FEB & MAR & APR & MAY & JUN & JUL & AUG & SEP & OCT & NOV & DEC & ANN \\
\hline 1990 & 27.68 & 28.51 & 28.7 & 29.94 & 29.91 & 29.07 & 29.06 & 29.41 & 30.7 & 31.76 & 30.92 & 28.69 & 29.53 \\
\hline 1991 & 28.15 & 27.72 & 28.66 & 28.45 & 29.3 & 29.22 & 29.01 & 30.1 & 31.84 & 32.27 & 29.38 & 28.92 & 29.43 \\
\hline 1992 & 28.27 & 27.91 & 29.11 & 28.57 & 28.79 & 29.19 & 28.87 & 28.58 & 29.05 & 28.67 & 28.38 & 27.92 & 28.61 \\
\hline 1993 & 27.19 & 27.62 & 28.45 & 28.02 & 28.83 & 28.59 & 28.79 & 28.79 & 29.81 & 30.6 & 29.92 & 28.68 & 28.78 \\
\hline 1994 & 27.45 & 27.54 & 27.79 & 28.47 & 28.63 & 28.56 & 28.39 & 29.39 & 30.97 & 31.73 & 30.89 & 29.16 & 29.09 \\
\hline 1995 & 27.67 & 27.48 & 28.35 & 28.59 & 28.98 & 28.63 & 28.28 & 29.46 & 29.8 & 29.57 & 28.88 & 28.17 & 28.66 \\
\hline 1996 & 26.81 & 26.81 & 28.11 & 28.93 & 29.41 & 28.74 & 29.26 & 29.13 & 30.04 & 29.58 & 29.03 & 28.13 & 28.67 \\
\hline 1997 & 26.94 & 27.2 & 28.97 & 28.35 & 29.1 & 29.21 & 28.69 & 29.4 & 31.47 & 32.92 & 31.79 & 29.86 & 29.5 \\
\hline 1998 & 30.31 & 29.08 & 28.96 & 29.29 & 29.65 & 28.6 & 28.44 & 29.33 & 29.67 & 28.64 & 28.45 & 28.44 & 29.07 \\
\hline 1999 & 27.58 & 27.32 & 28.22 & 28.93 & 28.64 & 28.66 & 28.53 & 29.33 & 30.97 & 29.96 & 28.95 & 28.42 & 28.8 \\
\hline 2000 & 27.45 & 27.57 & 28.04 & 28.66 & 28.79 & 28.79 & 29.17 & 29.65 & 31.36 & 30.39 & 29.17 & 30.27 & 29.11 \\
\hline 2001 & 28.13 & 28.15 & 28.14 & 28.91 & 29.38 & 28.55 & 28.66 & 29.37 & 30.46 & 29.6 & 28.67 & 29.36 & 28.95 \\
\hline 2002 & 27.97 & 27.05 & 28.72 & 28.65 & 29.34 & 29.09 & 28.71 & 29.21 & 30.16 & 31.99 & 30.68 & 29.59 & 29.28 \\
\hline 2003 & 30.46 & 27.97 & 28.77 & 29.79 & 29.79 & 29.89 & 30.12 & 30.71 & 31.02 & 30.98 & 29.92 & 28.6 & 29.85 \\
\hline 2004 & 28.26 & 27.61 & 28.21 & 29.37 & 29.24 & 28.85 & 28.6 & 29.29 & 30.27 & 31.27 & 30.33 & 28.52 & 29.15 \\
\hline 2005 & 28.1 & 28.28 & 27.98 & 28.96 & 29.37 & 28.87 & 28.73 & 29.25 & 29.92 & 29.84 & 29.56 & 28.6 & 28.96 \\
\hline 2006 & 27.84 & 28.2 & 27.9 & 28.56 & 28.64 & 28.75 & 28.89 & 29.25 & 30.87 & 32.55 & 31.69 & 29.55 & 29.39 \\
\hline 2007 & 30.05 & 28.04 & 28.07 & 28.67 & 28.89 & 28.77 & 28.84 & 29.2 & 30.43 & 30.7 & 29.94 & 28.5 & 29.18 \\
\hline 2008 & 28.83 & 26.79 & 27.99 & 28.39 & 28.93 & 28.75 & 28.88 & 29.2 & 30.51 & 30.5 & 29.17 & 28.47 & 28.88 \\
\hline 2009 & 27.89 & 27.35 & 28.5 & 28.91 & 28.96 & 28.89 & 29.04 & 29.68 & 31.06 & 30.55 & 29.93 & 29.38 & 29.19 \\
\hline 2010 & 28.08 & 29.06 & 28.83 & 29.89 & 29.45 & 28.4 & 28.36 & 28.52 & 28.78 & 28.39 & 28.35 & 27.38 & 28.62 \\
\hline 2011 & 26.91 & 27.64 & 27.85 & 28.6 & 28.69 & 28.82 & 28.7 & 29.23 & 30.15 & 30.14 & 29.32 & 29.21 & 28.78 \\
\hline 2012 & 28.32 & 28.61 & 28.6 & 28.69 & 29.44 & 29.09 & 29.1 & 30.22 & 31.53 & 30.71 & 29.66 & 28.99 & 29.41 \\
\hline 2013 & 27.6 & 28.22 & 29.22 & 28.73 & 28.79 & 28.79 & 28.28 & 29.2 & 30.22 & 30.39 & 29.51 & 28.52 & 28.96 \\
\hline 2014 & 27.14 & 27.28 & 28.46 & 29.21 & 29.56 & 29.15 & 28.93 & 29.27 & 30.23 & 30.75 & 29.99 & 28.66 & 29.06 \\
\hline 2015 & 27.76 & 27.67 & 28.28 & 28.65 & 29.4 & 29.31 & 29.1 & 29.79 & 31.38 & 32.84 & 31.1 & 29.54 & 29.58 \\
\hline 2016 & 29.8 & 28.77 & 29.21 & 29.44 & 29.47 & 29.21 & 28.92 & 29.46 & 29.18 & 28.41 & 28.32 & 28.48 & 29.06 \\
\hline 2017 & 27.92 & 27.64 & 28.48 & 28.58 & 29.46 & 28.71 & 28.96 & 29.47 & 30.36 & 29.82 & 29.49 & 28.64 & 28.97 \\
\hline 2018 & 28.12 & 27.75 & 28.98 & 29.35 & 29.7 & 29.29 & 29.35 & 29.77 & 30.75 & 31.39 & 29.65 & 29.38 & 29.47 \\
\hline 2019 & 28.59 & 29.23 & 29.11 & 29.64 & 29.72 & 29.44 & 29.21 & 29.67 & 31.42 & 32.58 & 31.72 & 30.18 & 30.04 \\
\hline Rata-rata & 28.11 & 27.87 & 28.49 & 28.91 & 29.21 & 28.93 & 28.86 & 29.41 & 30.48 & 30.65 & 29.76 & 28.87 & 29.13 \\
\hline Maksimum & 30.46 & 29.23 & 29.22 & 29.94 & 29.91 & 29.89 & 30.12 & 30.71 & 31.84 & 32.92 & 31.79 & 30.27 & 30.04 \\
\hline Minimum & 26.81 & 26.79 & 27.79 & 28.02 & 28.63 & 28.40 & 28.28 & 28.52 & 28.78 & 28.39 & 28.32 & 27.38 & 28.61 \\
\hline
\end{tabular}

